\title{
MAPS, DIAGRAMS AND TABLES
}

\section{MAPS, DIAGRAMS AND TABLES}

Map 1: Nigeria: showing position of Okuku xii

Map 2: Okuku c. 1975: showing public buildings and principal compounds

Map 3: Okuku and neighbouring towns

Map 4: 'Towns of origin'

Fig. 1: Genealogies of the Olokuku

Fig. 2: Descendants of Awotutu and Aworọa 169

Fig. 3: Așapawo's ancestry 251

Table 1: Reigns of the Olokuku 54

Table 2: Chiefs in Okuku (1975) 188

Appendix: Ile in Okuku

Plate 1. His Highness James Oloṣebikan Oyclousi II

Plate 2. Sangowẹmi

Plate 3. Sangowemi

Plate 4. A bride

Plate 6. A royal bride

Plate 6. Faderera 